Research Article

\title{
Classroom and music teachers' perceptions about the development of imagination and creativity in primary music education
}

\author{
Sehnaz Sungurtekin \\ Bursa Uludag University, Faculty of Education, Turkey
}

\begin{abstract}
Despite the importance of musical creativity in combining existing musical knowledge in novel ways, research suggests that primary school teachers' practices do not adequately stimulate and develop children's musical creativity. In this regard, the purpose of this paper was to investigate teachers' perspectives on the development of imagination and creativity in primary music education. A phenomenological study approach was adopted to better understand how classroom and music teachers experience and ascribe meaning to imagination and creativity, as well as to assess the status of the two phenomena in primary music education. The results demonstrated that classroom and music teachers thought imagination and creativity were important for improving students' learning skills, underlining the importance of these phenomena in music education. Teachers linked product learning to student performances in playing their own instruments, creating rhythms with various materials, and writing poetry and lyrics. While a few music teachers emphasized the creation of melodies and rhythms, no emphasis on structural and intentional composing, and no product descriptions were provided. Teachers' thoughts on what adjustments need to be made within the primary music curriculum to equip students as imaginative and creative thinkers are also covered in this article following the introduction of a creative curriculum in primary music education.
\end{abstract}

Keywords: Imagination; Musical creativity; Primary music education; Music teachers; Classroom teachers; Creative curriculum development

Article History: Submitted 19 February 2021; Revised 22 June 2021; Published online 26 August 2021

\section{Introduction}

I want the notes to glide through the air while playing the piano... to fly one at a time. (Eda, ten years old)

On top of imaginary clouds, I would like to play instruments.... and create a choir, and once in a while, sing a song to people beneath the clouds. (Suhal, ten years old)

Through the magical potential of imagination that occurred within the creative process, we transformed the world into another level of human achievement, and still, we continue to change it

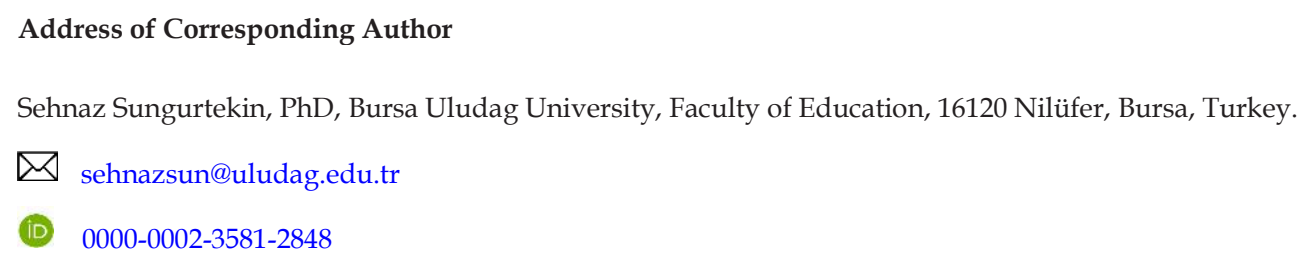

How to cite: Sungurtekin, S. (2021). Classroom and music teachers' perceptions about the development of imagination and creativity in primary music education. Journal of Pedagogical Research, 5(3), 164-186. http:// doi.org/10.33902/JPR.2021371364 
so. We may be able to go beyond history if we take a step back and reconsider the importance of imagination and creativity in our lives. All social activities and various kinds of human products started first with the imagination. Therefore, it is essential to profoundly understand this phenomenon and emphasize its significance in education. As a researcher, it is very inspiring to think about education, where children become masters of their own imagination and creativity. The extracts above show children's inherent and immense creative potentials. Robinson (2009) pointed out that the current education system drains the creativity out of our children.

"Education is the system that's supposed to develop our natural abilities and enable us to make our way in the world. Instead, it is stifling the individual talents and abilities of too many students and killing their motivation to learn. There is a huge irony in the middle of all of this." (Robinson, 2009, p. 16)

Based on Robinson's quote, as in all fields of education, music educators and researchers should re-think the concepts of imagination and creativity in music education. Musical creativity plays a fundamental role in children's musical and holistic development; however research suggests that primary school teachers may not be appropriately challenging their students' musical creativity (Joubert, 2001; Koutsoupidou, 2005, 2008; Langley, 2018). As a result, one of the most important issues is how teachers might think about imagination and creativity in the classroom. Are teachers aware of students' creative requirements, as well as their creativity and musical learning and growth potential? Another concern arising from Blake's (2011) research is how music teachers may assist "each student" in making creative contributions in the music classroom. After hearing a student say about a song they had created the week before, "Those were Elise's thoughts," one of the teachers silently questioned himself this question.

There has been concern in the last fifty years that education should emphasize creative development; various attempts to increase learner creativity have been established under this notion, but there is currently little study into growing and accessing students' creativity (Craft, 2002). Furthermore, researchers have devoted less attention to the impact of music on creativity than they have to other types of learning (Hallam, 2010). There is still a lack of experiential studies in Turkey that pay attention to imagination and creativity in schools. The need for qualitative studies has a significant impact on understanding teacher perceptions of creativity in more depth; also, it is compelling as it relates to the classroom context and the discourse of creativity in education (Mullet et al., 2016). Only a few studies in the past, such as the research of Blacking (1967), Upitis (1992), and Campbell (1998) have an investigative focus on children's musical thinking, as well as the nature of their musical experiences and the meanings they attribute to these experiences (as cited in Burnard, 2000).

Joubert (2001) stresses that teachers do not always offer children opportunities to become involved in creative activities. When facing formal structures in school and the classroom, students often lose their natural power of imagination. In Langley's (2018) mixed-method study, students' and teachers' perceptions of creativity within choral classes were investigated. Students voiced displeasure with the lack of creative activities in their classes. According to the findings, teachers valued creativity but addressed it infrequently and were most influenced by a lack of confidence in conducting creative lessons. Other research findings indicate that teachers feel pressured to obtain correct and exact answers from their students rather than allowing for creative responses (Kettler et al., 2018). Moreover, teachers usually prefer well-behaved students to creative students, who are often perceived as trouble-makers, and families (most Americans) prefer their children's respect for their elders to independence, good behaviour to curiosity, and respect for rules to creativity (Eagleman \& Brandt, 2017). As long as these perceptions continue, it does not seem easy to nurture and develop children's and young people's imaginative and creative thinking.

Hickey and Webster (2001) described the creative process as "the thinking that takes place as a person is planning to produce a creative product" (p. 20). According to Webster's model of creative thinking in music, the complex creative process begins with an idea or intention and ends with a creative product. However, he points out that educators should use the term 'creative 
thinking' in referring to creativity because he thinks that 'creative thinking' focuses on the process of creativity and not the product (Webster, 1990). According to Hickey (2012), creative thinking is the ability to think imaginatively and "the act of manipulating old ideas and creating new and original musical ideas." (as cited in Reesman, 2015, p. 11).

Creativity is related to the development of imagination (Higgins, 2008), a central part of musical experiences, whether composing, listening, or performing (Reichling, 1997). Musical creativity in schools can occur in different activities such as listening, performing, improvising, and composing (Koutsoupidou, 2005). Composition and improvisation are mostly accepted as the main activities for creating new musical ideas, which refers to musical creativity. Music listening and performance, on the other hand, are considered as additional forms of creative behavior (Kokotsaki, 2012).

Webster (2002) describes three fundamental ways that humans engage in musical behaviour. First, the most common behaviour is listening, the second one is composition, which is the least typical behaviour, and the third one is performance.

"Performance is really divided into the reproduction of music written by others and the creation of music "at the moment" within a context - often referred to as "improvisation." Although there are settings where teaching and learning are focused primarily on one or the other, each behaviour is mutually supportive of the other in our quest as music educators to teach about music. Good music teaching usually involves all three types of behaviours." (Webster, 2002, p. 4)

Before thinking of good music teaching in the 21st century, we must first consider what teachers must do differently to spark students' imaginations. Another aspect to consider is the relevance of creativity in a child's holistic development. In his study, the developmental psychologist Paul Harris (2000) claims that children's imaginings and fantasies in the early years (from their second year onward) are not as disorganised or primitive as we think. Children can imagine hypothetical circumstances and counterfactuals, as evidenced by their sophisticated dramatic plays. Furthermore, their imagination has an impact on their cognitive and emotional development, as well as their ability to make causal and moral judgments (Trivedi, 2017). Harris's statement may show how crucial it is to consider and appreciate children's imagination in schools. Accordingly, it is necessary to examine in depth teachers' perceptions and experiences towards imagination and creativity in music education. On the other hand, Skiba et al. (2010) noted that in an educational system that prioritises traditional teaching approaches, understanding teachers' perceptions of creativity must precede attempts to develop a pedagogy of creativity.

Developing an accurate understanding of teacher perceptions about creativity seems to be important and necessary to obtain information on implementing and incorporating creativity effectively in the classroom (Mullet et al., 2016). The imagination is seen as a fundamental component of developing musical creativity in the primary classroom. In a qualitative study by Sungurtekin and Kartal (2020), primary school students at the age of 10 were asked about how they imagined their music lessons in school. The statements relevant to their imaginations were first about the learning settings (music camp-tents outside school, music hall-clubs, etc.), playing different instruments and the music activities they wished to do in their classroom. Giving voice to children may be the first step in developing their awareness to master their own imagination and creativity.

The purpose of this study was to examine classroom and music teachers' perceptions of the development of imagination and creativity in primary music education and understand how they experience and ascribe meaning to these phenomena. Within this investigative approach, we may attain an understanding of how teachers shape their primary music lessons to allow children to express their ideas and imaginations in multiple ways. Based on the aforementioned conceptual framework, the following research questions are addressed:

1. What are classroom and music teachers' perceptions of imagination and creativity in primary music education? 
2. How do teachers develop and implement good classroom practices to develop students' imagination and musical creativity?

3. What changes do teachers think need to be made within the primary music curriculum to prepare students as imaginative and creative thinkers?

\section{Method}

\subsection{Research Design}

A qualitative research method with a phenomenological research design was utilized in this study. This approach focuses on experiences from the perspective of the person who is experiencing the phenomenon (lived experience) and on the content of conscious experiences, such as judgments, perceptions, and emotions (Conelly, 2010). The phenomenological approach enables re-thinking the complex phenomena that the individual encounters in the dynamic and challenging world of the 21st century (Dall' Alba, 2009). In this regard, the study aimed to examine classroom and music teachers' perceptions of imagination and creativity in primary music education and understand how they experience and ascribe meaning to these phenomena. Therefore, phenomenology is used as an effective methodology for this research since it allows exploring participants' experiences and perceptions towards imagination and creativity, which are seen as the phenomenon in this study. According to Selvi (2014), individuals' creative acts concerning the event can reveal new meanings by utilizing scientific methods such as perception, observation, imagination, and creativity.

One of the weaknesses of qualitative research is that it is not generalisable and includes a small number of participants. However, "in the process of even investigating the experience of one unique individual we can learn much about the phenomenology of the human being in general... and they can be phenomenologically informative" (Hycner, 1985, p. 295).

\subsection{Participants}

The study consisted of 17 teachers (12 female, five male, aged 26-50) who agreed to participate voluntarily in this research during the period of September-December 2020. In selecting teachers, specific criteria were set for collecting in-depth and relevant data for the purpose of this research. Therefore, a purposeful sampling strategy was conducted. For the level of insights of teachers who would provide a wide range of descriptions and interpretations about how they perceive the phenomena (imagination and creativity in primary music education), the research included participants with at least five years of experience teaching music in primary schools.

Eight teachers were music teachers working at private primary schools, and nine were classroom teachers in state schools, teaching from the 1st-grade level up to the 4 th grade. Four of the classroom teachers have a master's degree in educational sciences. The primary schools were selected randomly in a district where the private schools are mainly located. Music teachers in Turkey are appointed in state secondary or high schools, not in public primary schools, which is why private schools are preferred. To keep the data confidential, all teachers are identified using a pseudonym with the codes MT for music teachers, CT for classroom teachers, and PCT for postgraduate (master's degree) classroom teachers (see Table 1).

\subsection{Instrument}

The study instrument was an online open-ended questionnaire created in Google Workspace that was divided into two portions. The first section provided demographic information and five questions to help participants identify themselves. The second section consisted of six open-ended questionnaire prepared to learn about their experiences with imagination and creativity in primary music education and how they assigned significance to them. Teachers were requested to share information about how they develop and implement appropriate classroom practices to 
Table 1

Demographic information of teachers

\begin{tabular}{lclclc}
\hline $\begin{array}{l}\text { Field of } \\
\text { occupation }\end{array}$ & $\begin{array}{c}\text { Years of } \\
\text { experience }\end{array}$ & $\begin{array}{l}\text { Field of } \\
\text { occupation }\end{array}$ & $\begin{array}{c}\text { Years of } \\
\text { experience }\end{array}$ & $\begin{array}{l}\text { Field of } \\
\text { occupation }\end{array}$ & $\begin{array}{c}\text { Years of } \\
\text { experience }\end{array}$ \\
\hline MT $^{*}$ & & PCT $^{* *}$ & & CT $^{* * *}$ & \\
\hline Gizem (F) & 26 & Deniz (F) & 12 & Irem (F) & 24 \\
\hline Oya (F) & 16 & Filiz (F) & 12 & Alp (M) & 12 \\
\hline Umut (M) & 14 & Canan (F) & 9 & Zerrin (F) & 9 \\
\hline Ufuk (M) & 12 & Melis (F) & 6 & Emel (F) & 7 \\
\hline Buse (F) & 8 & & & Enis (M) & 6 \\
\hline İlhan (M) & 5 & & & & \\
\hline Begüm (F) & 5 & & & & \\
\hline Demet (F) & 19 & & & & \\
\hline
\end{tabular}

Note: (F): Female; (M): Male; *Music teacher; **Postgraduate classroom teacher; ${ }^{* * *}$ Classroom teacher

encourage students' imagination and musical creativity, as well as an example of a music lesson that included both. A question from Kokotsaki's study (2012) was generated in relation to the following music lesson example to further clarify the data: In your teaching example, what would you look for as evidence of imaginative and creative thought? The last question focused on teachers' opinions about what changes need to be made within the primary music curriculum to prepare students as imaginative and creative thinkers. The questionnaires were sent via e-mail to the participants. After collecting all answers, a semi-structured interview was carried out as a follow-up data collection tool to obtain an in-depth understanding of teachers' perceptions and to clarify their interpretations and reflections on the research topic. Due to the COVID-19 pandemic, the interviews were undertaken through virtual meetings on Google Meet and recorded with each participant's permission. The interviews lasted approximately forty-five minutes to one hour.

\subsection{Data Analysis}

In phenomenologically analysing the data, a step-by-step procedure is followed within a thematic approach. The thematic approach consists of an analysis process for encoding qualitative information (Boyatzis, 1998) and focuses on identifying and describing implicit and explicit ideas within the data/themes (Guest et al., 2012). The thematic analysis technique was used in this study since the themes became categories for analysis and provided a pattern recognition within the data (Fereday \& Muir-Cochrane, 2006).

In the first step of the analysis procedure, the interview data were transcribed by the researcher. According to Hycner (1985), "this includes the literal statements and as much as possible, noting significant non-verbal and paralinguistic communication" (p. 280). He emphasized the significance of viewing a phenomenon in its entirety, including its meaning and structure. The researcher must approach the phenomenon with an open mind, recognizing its inherent significance. In this respect, the interview data were transcribed and analysed as a whole in order to understand the meaning of participants' expressions, perceptions and interpretations. Therefore, the units of general meaning were described, and codes were generated and bracketed. The focus was to divide the interview data/text into units. The next phase was to describe the units and their meanings related to the research questions. Hycner (1985) described this as a critical phase and emphasised that "the researcher addresses the research question to the units of general meaning to determine whether what the participant has said responds to and illuminates the research question" (p. 284). In this sense, irrelevant statements were not recorded. The relevant units transformed into meanings were categorised in common themes and contextualised to understand the role between the phenomena and the context in this research. A general description of the findings was composed to provide detailed information about participants' articulations and experiences relevant to the examined phenomena (imagination and creativity in primary music education). 


\subsection{Trustworthiness of the Research}

Trustworthiness is considered to be an essential scientific criterion in qualitative research. Guba and Lincoln (1982) emphasised the need in referring to trustworthiness in qualitative research rather than validity and reliability and grouped trustworthiness criteria in four main headings: credibility, dependability, confirmability and transferability (as cited in Baskale, 2016). Prolonged engagement, peer debriefing, triangulation and member checking are a series of techniques to increase the credibility of the research (Amankwaa, 2016).

In revealing trustworthiness in this research, a prolonged engagement was established during the interviews based on mutual trust and interaction to obtain accurate data and understand the participants' perceptions and experiences deeply. Specific questions were asked in each phase of preparation, organisation, and reporting (Elo et al., 2014) to ensure the trustworthiness of the analysis in this study. These are related to the data collection method, sampling strategy, selecting the unit of analysis, how the codes and categories are created, the degree of interpretation, and questions to ensure that the data accurately represent the teachers' information. As mentioned previously, the research instruments were developed from the related literature. Some of the interview questions were adapted and developed based on Kokotsaki's study (2012). In this respect, the instruments have been proven in the criteria of credibility and transferability.

The member checking technique was used to confirm whether the collected data reflect teachers' answers correctly and the consistency of their perceptions over time. A verification procedure was conducted after the first content analysis related to the online questionnaire. The data obtained were confirmed by the teachers one by one during the online interviews to avoid misconceptions. Additionally, this procedure allowed teachers to make additional statements to their experiences and explanations within the interview questions. Furthermore, a peer debriefing strategy was conducted with an expert in the field for the authenticity and consistency of data, findings and all research documents (open-ended online questionnaire, recordings and transcriptions of the interviews). The research instruments and the ongoing analysis and findings were discussed and criticised with the expert to verify that the categories cover the data accurately. The data analysis was carried out within a continuum where the related concepts were classified and described to establish links between categories and the phenomena. The categories were created according to the literature about the different aspects of imagination and creativity in primary music education. This provided to examine the consistency of data and findings within a triangulation technique.

The expert had information about the research procedure and the data collection process but was independent of the study to make relevant judgements and had no contact with the teachers.

After the critique process, a consensus was reached between the expert and researcher, but the mutual critique process was continued regularly during the reporting phase. Direct quotations of the teachers were reported in order to ensure the credibility of the research.

\section{Findings}

\subsection{Imagination in Primary Music Education}

When the expressions of teacher about imagination in primary music education were analysed, eight key categories emerged: Expression, association with nature, distinctive characteristics, integration into music lessons, process and product, a spiral form with the arts/music, metaphor, and transformation. Table 2 displays the obtained results. 


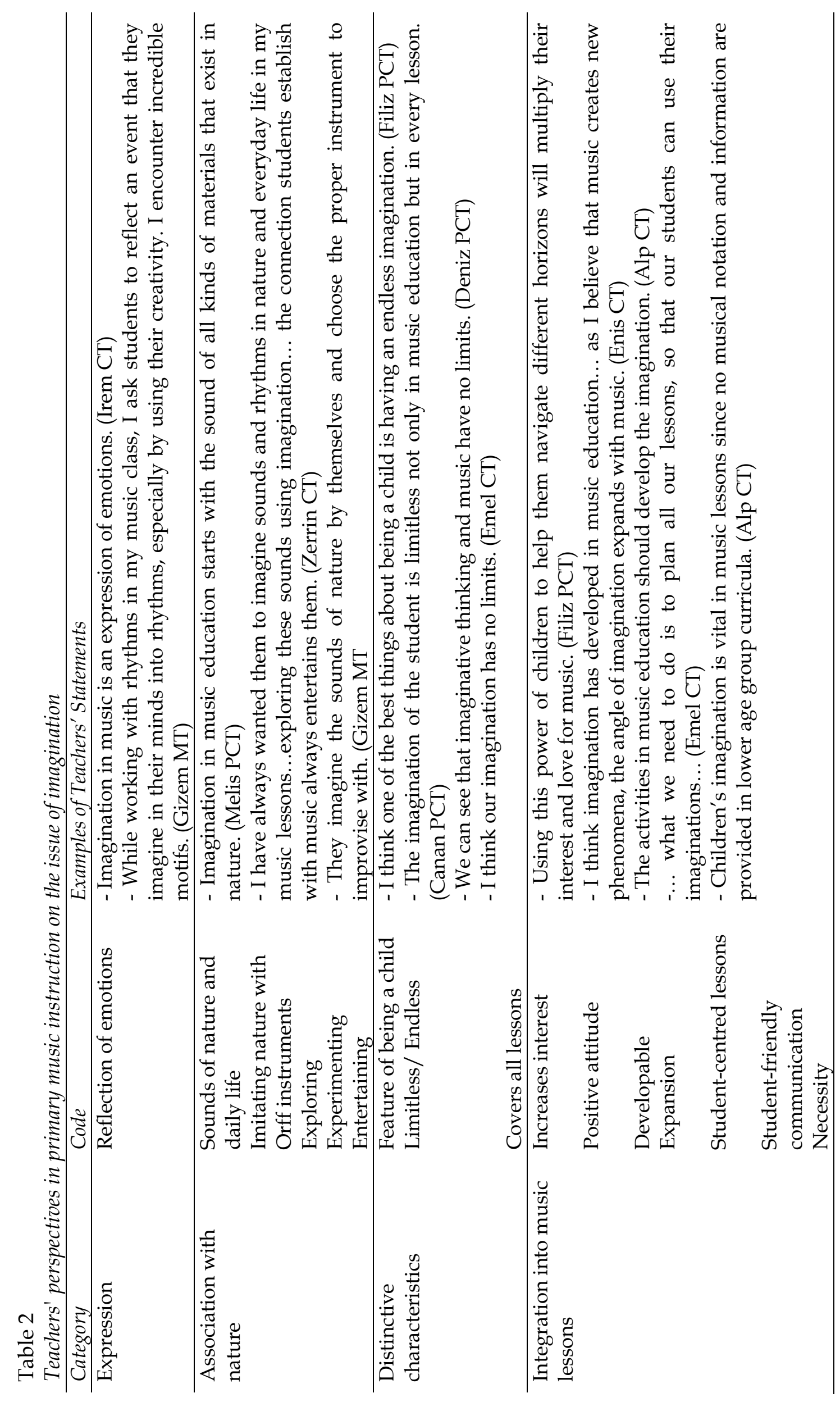




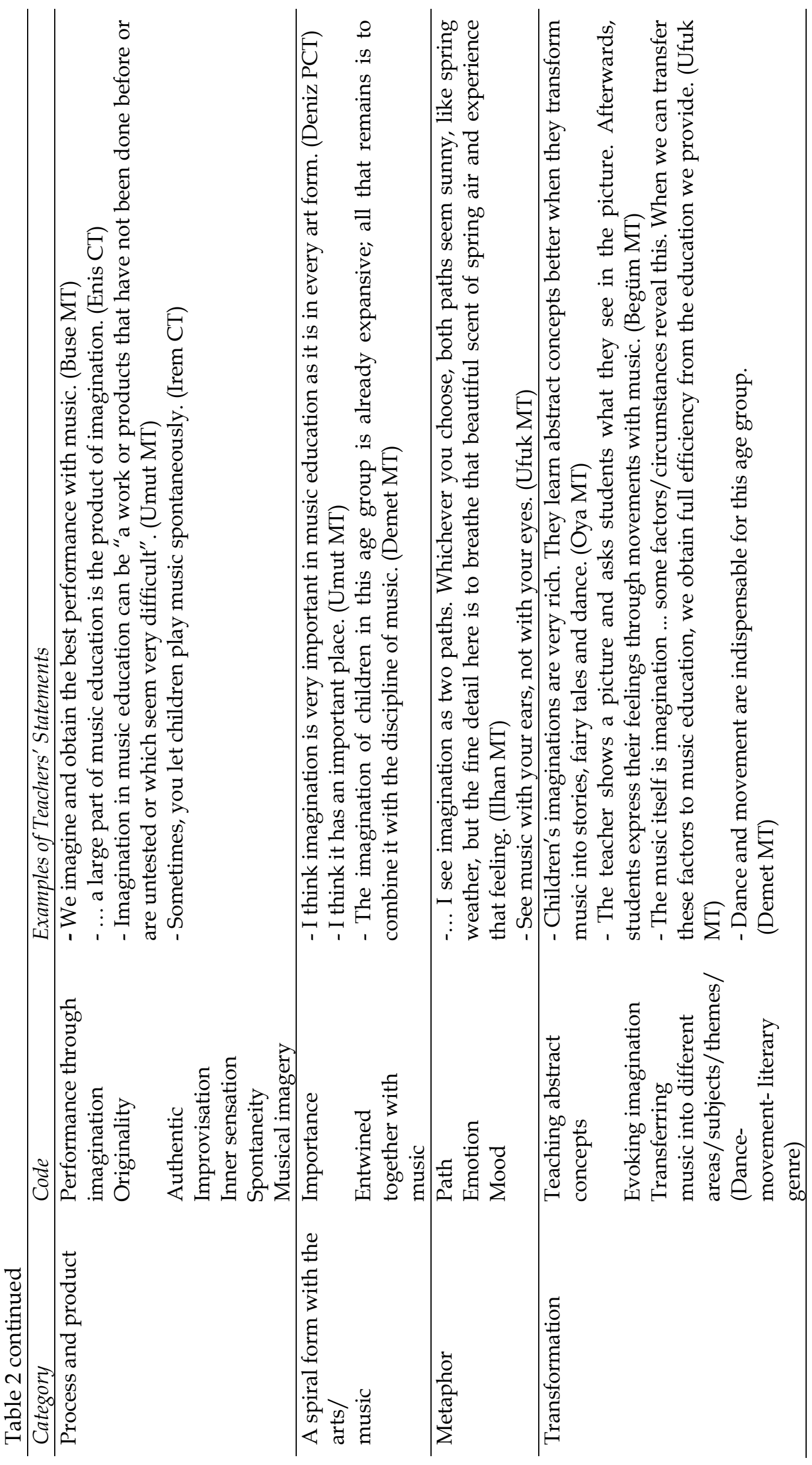


When asked how they would define and explain imagination in music education, the majority of the teachers reflected on the transformation of the imagination; for example, learning can be more effective when imagination is stimulated in music lessons within different subjects, themes, or topics and in this way, students can acquire abstract concepts better. Furthermore, most teachers employ music in their lessons to elicit the imagination of their students. Some of the comments seemed to describe the unique qualities of imagination; for example, this phenomena was viewed as a limitless aspect of the child that may manifest itself in music instruction, as well as in each lesson and subject at the primary school level. Three teachers linked imagination to nature; for example, students might imagine the sounds of nature and everyday life, then imitate and improvise with Orff- instruments or natural materials. It is understood that these teachers perceive imagination in primary music education as the students' exploring and experimenting with all kinds of sounds and materials from their immediate surroundings and then reflecting their ideas in the music class in different ways. Such activities appeal to their imagination. Interestingly, two teachers used metaphors to describe this phenomenon. Regarding how and why educators need to consider and appreciate the imagination in the early years, one of the classroom teachers pointed out that:

"We need to plan all our lessons, including music education, so that our students can use their imaginations and open up their imaginations to us because for me, the way to understand better what children cannot say, especially in pre-primary school years, is to access their imaginations." (Emel CT)

\subsection{Creativity in Primary Music Education}

Teachers' perspectives regarding the creativity in primary music education were about the learning process, outcomes-products, and methods-techniques used to improve students' creativity and the importance and development of creativity. Creativity was linked to productbased learning, where students compose a known song differently or a new song on a particular topic (Emel CT) and create musical instruments from ready-made objects (Filiz PCT, Irem CT). Another teacher perception was that the more creative the child is, the better the product emerges (Zerrin, Alp CT). Some responses were that creativity requires originality; accordingly, music can enrich creativity because it involves developing new and different perspectives and expressing feelings and thoughts. Thus, students will always gain different thinking skills throughout their education, especially in learning environments that enable them to think and feel free. Some teachers also drew attention to individual differences in creativity. Creativity in the music classroom can change according to students' characteristics, experiences and choices during their learning process. According to Umut (MT), creativity is a concept that is based on correct knowledge. It has an important and different place in music education or rather informal education. Ilhan (MT) explained the priority for creativity as, "Merely singing and playing builds walls in front of creativity after a while. The most important thing is that we should meet the students' wishes and desires to develop their creativity." Every child's creativity can be nurtured in all elementary school lessons. Teachers stressed that individuals creativity improves with good music education, and the individual becomes more aware of owns creativity over the years.

Moreover, some teachers made connections between creativity and imagination. For instance, Ufuk (MT) asserted that "....creativity depends on the richness of our imagination; the more you imagine, the more your creativity in music exists. In music education, we can reveal this creativity with games and dance instead of questions and answers."

\subsection{Developing and Implementing Good Classroom Practices to Develop Students' Imagination and Musical Creativity: Teachers' Perspectives}

The classroom and music teachers illustrated various classroom practices that enable the development of imagination and musical creativity in their classroom (see Table 3). 


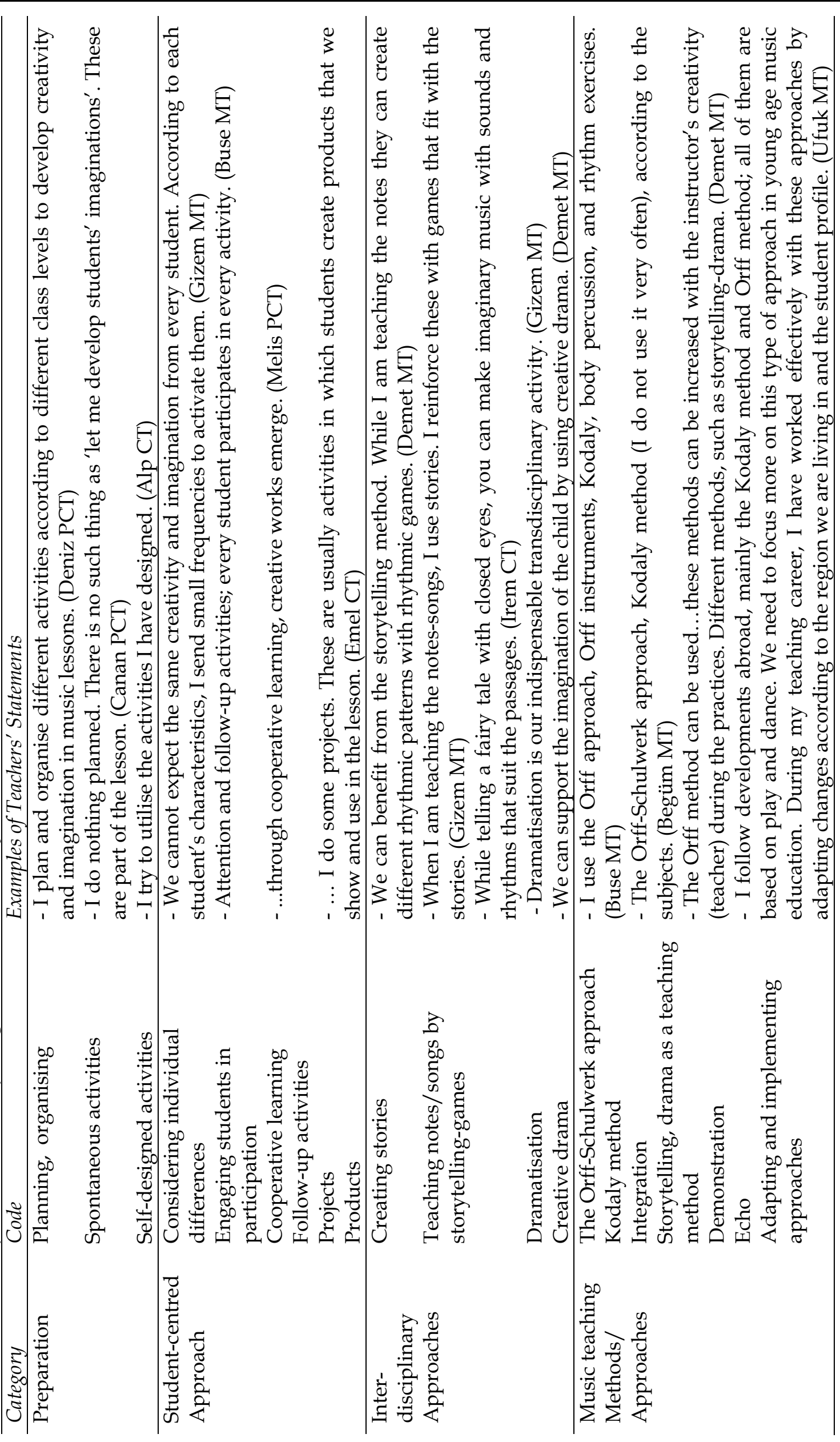




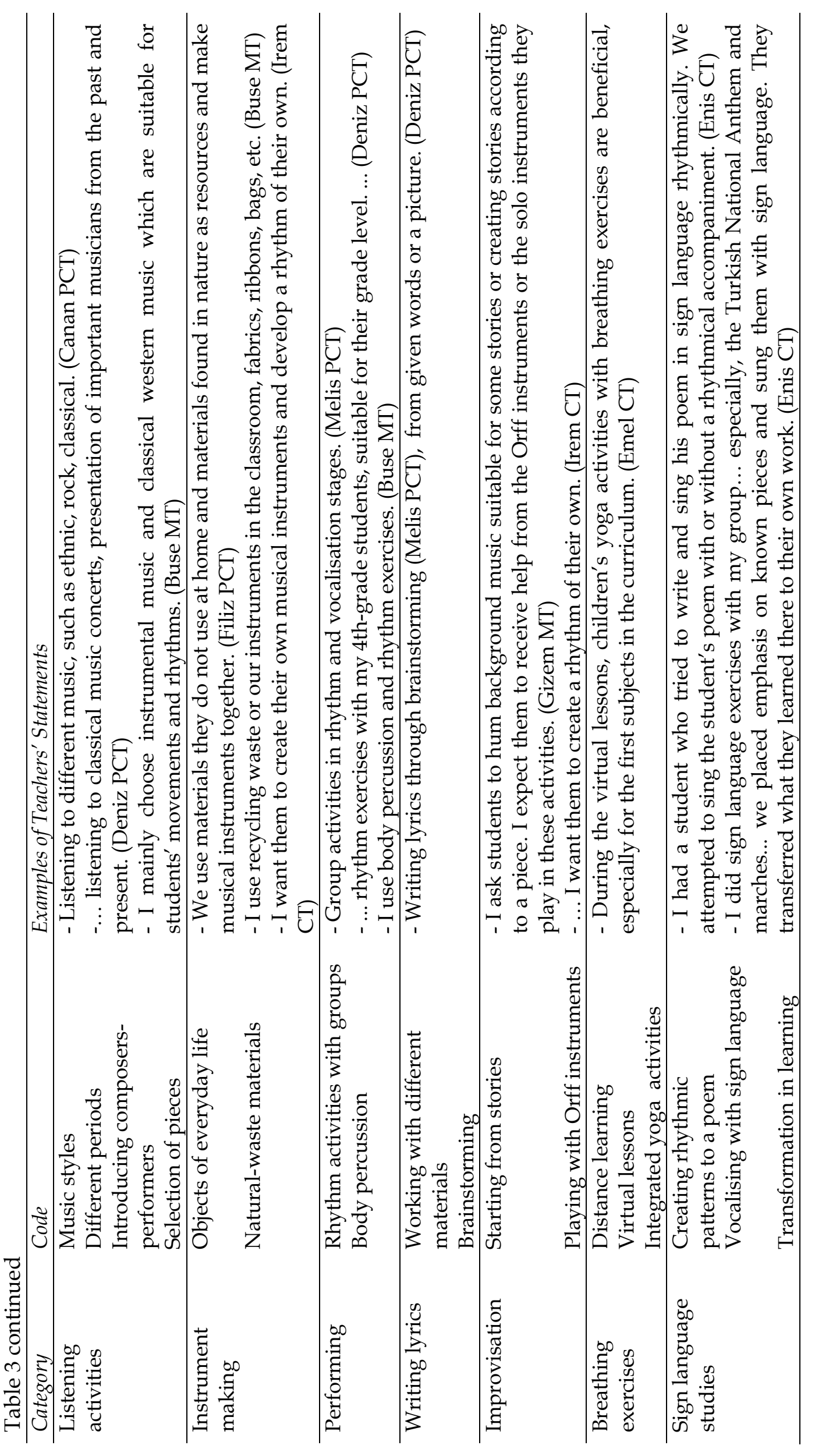


Most of the teachers stated in their interviews that they prepared and applied student-centred musical activities, some of which were product-project based. Teachers' focus was on considering students' identities (differences) and engaging students in group work to improve cooperative and collaborative learning. Students' full participation in musical activities was perceived as valuable in all teaching and learning. Only music teachers stated music teaching methods and approaches such as Orff-Schulwerk and Kodaly. According to classroom teachers' responses, creating rhythmical patterns on instruments (mostly self-made instruments with different materials), body percussion exercises, and working with lyrics-poems-stories were music activities that they implemented in their classrooms.

The use of resources for preparing and planning music teaching for imaginative and creative music lessons is presented in Table 4.

Table 4

Teachers' statements about resources for planning their music lessons

\begin{tabular}{|c|c|c|}
\hline Category & Code & Examples of Teachers' Statements \\
\hline $\begin{array}{l}\text { Digital } \\
\text { resources }\end{array}$ & $\begin{array}{l}\text { Special } \\
\text { music } \\
\text { programs } \\
\text { Karaoke } \\
\text { Computer } \\
\text { games }\end{array}$ & $\begin{array}{l}\text { - We provide Prodigies music education in kindergarten and primary } \\
\text { school. Prodigies is the most up-to-date music education program for } \\
\text { children aged 4-13, interactive, fun, and worldwide. (Ufuk MT) } \\
\text { - I use karaoke, and songs on the internet. (Enis CT) } \\
\text {-... there are computer games specially prepared for music education. } \\
\text { Mozart's Musical Adventure and Jumpstart Music, which I use to } \\
\text { catch students' attention, endear them to the lesson and make them } \\
\text { think differently. (Umut MT) } \\
\text { - Public schools do not have sufficient materials and resources. I } \\
\text { usually benefit from examples on the internet. (Alp CT) } \\
\text { - I use the internet. (Buse- Ilhan MT) }\end{array}$ \\
\hline $\begin{array}{l}\text { Social } \\
\text { media }\end{array}$ & $\begin{array}{l}\text { YouTube } \\
\text { Instagram } \\
\text { Blog } \\
\text { Implementing } \\
\text { activities }\end{array}$ & $\begin{array}{l}\text { I follow music teachers on YouTube and Instagram; I implement their } \\
\text { activities in my classroom. (Alp, Canan CT) } \\
\text { - I try to apply the content that we see in social platforms which } \\
\text { impress us, or that we can develop with the most appropriate } \\
\text { materials. (Ilhan MT) } \\
\text { - ... I adapt activities from blog websites and implement them in our } \\
\text { classroom with the facilities we have. (Filiz GCT) }\end{array}$ \\
\hline $\begin{array}{l}\text { Music } \\
\text { Textbooks }\end{array}$ & $\begin{array}{l}\text { Instrumental } \\
\text { Choosing and } \\
\text { adapting } \\
\text { activities }\end{array}$ & $\begin{array}{l}\text { - ... I try to benefit from the instructions in some textbooks. I choose } \\
\text { those activities that are suitable for my class and apply them. (Alp } \\
\text { CT, Filiz GCT) } \\
\text { - I use textbooks like "Keyboard Teaching with Colours", I choose the } \\
\text { activities and implement them in the class. (Zerrin CT) }\end{array}$ \\
\hline $\begin{array}{l}\text { Other } \\
\text { materials }\end{array}$ & $\begin{array}{l}\text { Self- } \\
\text { developed } \\
\text { materials } \\
\text { methods }\end{array}$ & $\begin{array}{l}\text { - I usually use my own methods; I have a lot of work that I have } \\
\text { developed and collected. (Umut MT) } \\
\text { - I include all kinds of objects with which music can be associated. } \\
\text { Tulle, stones, rhythmic patterns, pictures, stories ...The list can be } \\
\text { extended depending on the imagination of the teacher. (Oya MT) }\end{array}$ \\
\hline
\end{tabular}

The findings show that teachers generally use the internet to develop their teaching materials. Social media platforms were cited as the most frequently used resources. Besides, textbooks are less often used. The reason for this is that most of the teachers are not satisfied with the music textbooks prepared by the Ministry of National Education. One of the reasons was emphasised as that the songs do not meet primary students' expectations; they are old-fashioned, dull or straightforward in terms of melody and lyrics. Moreover, the songs in these music textbooks do not have the quality and potential to develop imagination and creativity. 


\subsection{Examples of Music Lessons to Develop Students' Imagination and Musical Creativity}

Teachers were requested to provide an example of a music lesson that encourages students' imagination and musical creativity in another section of the data collection tool. The responses are categorized and described by themes.

\subsubsection{Dramatisation/drama practices}

Students' imagination and creativity are cultivated and supported, according to teachers, through storytelling, narratives, creative drama, dramatization, and games. While the music teacher teaches the notes through stories, students use rhythmic games to create various rhythmic patterns. Fairy tales were brought to life through a dramatic procedure including self-made instruments and songs. Ilhan (MT) mentioned one of his music lessons in which students used role-playing to relate music with nature as by stating:

"I arouse curiosity in children with questions about what all the sounds in nature tell us by listening to different voices. After eliciting further comments from each student, I explain that birds can also create a choir, elephants can keep the rhythm while walking; in fact, every sound in nature has a meaning. Afterwards, I ask them to create scenes by role-playing, including their hands, arms, and gestures. Then we discuss what the activity means for the students."

\subsubsection{Integrating music within different subjects/themes}

Some teachers suggested that music should be with other disciplines in the primary classroom, such as teaching mathematics with rhythms, making musical instruments with waste materials in the social studies lesson, and writing songs based on true tales in values education. During the interview, Canan (CT) gave an example about her teaching in the Turkish lesson by role-playing; for instance, she improvised like an opera singer while reading a text, which seemed to be a kind of speech singing. One of the music teachers' statements in the following might illustrate an implicit example of inductive learning based on teaching music through dancing:

"I love working with tulle. It helps in teaching the phrase structure of a piece of music/song, etc. I ask students to create a dance phrase by listening to music. Then we create a dance performance with all the musical phrases/motifs created by the students. We practise by beginning with a short musical idea and ending with the whole piece of music. Sometimes we perform with tulles in different groups and colours or individually." (Oya, MT)

\subsubsection{Rhythmic accompaniments with body percussion, instruments, and other materials}

Students participate spontaneously with rhythmic accompaniments to songs by using body percussion or materials such as pencils, books, paint cans, tables. Teachers believe that the learning process becomes even more enjoyable in this way. Some teachers stated that they transfer to instruments after working with the body and materials in rhythmic activities.

\subsubsection{Improvisation}

Improvising stories by listening is one of the creative activities that Umut (MT) does in the classroom. For instance he asserted that:

"I taught the difference between "major and minor" by playing the piano. The students learned whether the songs they listened to were in major or minor keys. I asked students to write stories about what they felt while playing simple major and minor tunes. In the following lesson, we obtained very successful results with 2nd graders and 3rd-4th graders."

Alp (CT) explained that his students' write poems in groups. Afterwards, they perform the poems rhythmically with the instrument they have created. Another activity was mentioned where students improvise in an Orff ensemble (Buse MT). The student conductor conducted the ensemble according to his/her imagination and creativity. Arousing curiosity to ensure full participation of the students in the lessons was another music teacher statement. Ufuk (MT) gave examples such as; 
"Entering the class by singing a song students do not know or playing a different instrument they have never seen, wearing a costume, asking students, "How would you do it if you were...?", forming groups and leaving the stage to the students. In this way, creativity and imagination will emerge."

\subsubsection{Little composing activities}

According to the results, composing activities were mentioned by only a few music teachers. Students were asked to compose melodies by using five notes in Umut's (MT) music class. Students made simple compositions which were successful. In another example, students were asked to fill in the bars with the notes in line with the determined time signatures. The students created different rhythmic patterns and musical ideas that the music teacher (Begüm MT) found unique. After mixing all the motives and phrases, the children were asked to perform the rhythms using their bodies, working in pairs and groups. Afterwards, they combined vocal sounds (e.g. ca, $\mathrm{cu}$, bom, a, o) with movements and pitched/unpitched instruments.

One of the study's interview questions was on what teachers look for in their teaching examples to demonstrate imaginative and creative thinking. Teachers' responses to questions about evidence of imaginative and creative way of thinking in music lesson examples included creating tales and stories and performing them through songs and instruments (Filiz CT, Gizem MT), and interpretations of classical music with creative movements and dances (Filiz CT, Gizem MT) (Deniz CT, Oya, MT). Every novel, spontaneous, and unexpected thought, feeling, or sound, according to Canan (PCT), is evidence of imaginative and creative comprehension. Other evidence claims included creating rhythm and melody, expressing sentiments through music, conducting instrumental groups, creating their own instruments, and experimenting with various rhythmicmelodic ideas. Associating nature and music was also seen as evidence of imaginative and creative thought. Self-confidence, decision making, the reflection of one's own ideas, and active and free learning environments were stressed as concepts of imaginative and creative thinking.

\subsection{Teachers' Insights Regarding the Changes in the Primary School Music Curriculum for Developing Imagination and Creativity}

Teachers' responses to the research question, "What changes do you think should be done in the primary music curriculum to prepare children to think imaginatively and creatively?" were not only concerned with the curriculum, but also with the additional requirements for the development of primary school music education. The need to reorganise the primary music curriculum and the monthly/daily lesson plans in detail was stressed by some teachers (Begum MT; Deniz CT). Gizem (MT) stated that the most significant deficiency in the curriculum is that it does not focus on students' differences; instead, every student is accepted as being at the same level. Deniz (PCT) expressed her opinion as "I can say that this subject is lacking. The primary school music curriculum is not sufficient to develop children's creativity and imagination. This subject depends on the classroom teacher's initiative, which is a problem."

On the other hand, Alp (CT) noted that there is not enough information about musical concepts and music instruction in the current curriculum; therefore, the teacher must consider and integrate children's imagination in the learning process. Following this, the teacher must be creative and direct their musical teaching in this respect. Besides, some responses were not directly related to the music curriculum. For instance, in-service training in music education was stressed by all classroom teachers and the need for music specialists in primary schools. The reason was illustrated as due to their lack of music competencies. Some music teachers emphasised their lack of movement and dance pedagogy since the curriculum must be placed within this pedagogy (Oya, MT). In connection with the music curriculum, the importance of equality in education and special education for talented children was emphasised (Ilhan, Umut MT). More instructions on creative drama practices should be included in the primary music curriculum to provide detailed information to the classroom teacher for integrating drama in music lessons. Additionally, the 
number of music lessons should be increased; because time limitation makes it difficult to implement musical activities for developing imagination and creativity.

\section{Discussion}

The results of this paper revealed that classroom and music teachers perceive imagination as vital in primary music education. The benefits of involving imagination in music lessons were emphasised such as enabling students to express their emotions, exploring with sounds, associating music with nature, and expanding their interest in music activities. Transferring music to different disciplines and subjects was mentioned by both groups (classroom and music teachers), and the benefits were addressed, such as that it enables children to learn abstract concepts better by using their imaginative potential. Intrinsically, children's imagination already exists; more importantly, this potential should be integrated with music, as a large part of music education is the product of imagination. Dewey's theoretical knowledge of the value of imagination must be underlined at this point. According to him, images are "the motor power of an idea. With a little child, the idea, or image, tends to show itself in action" (Chambliss, 1991, p. 45). One way to understand Dewey's concept of imagination and its relation to reconstructing experiences is to observe the actions that images can reflect on themselves. Notably, "the child is taken up with direct and outgoing activity, based on images and emotions that possess his mind. There is always physical, motor activity; and there is always a story, drama, image - a mental whole" (as cited in Russel, 1998, p. 197). It can be claimed that in an environment where imagination is appreciated in teachers' teaching practices and a supportive classroom climate is developed, students' images will come to life with their direct actions. Furthermore, teachers need to instil in students a creative attitude to all music activities and encourage them to find new ways of exploring meaningful sounds through their imagination (Kokotsaki, 2012).

The creative process, in theory, begins with imagination, then moves on to improvisation, and finally, to a product with originality, something different and new (Ryan \& Brown, 2012). Some teachers' statements on imagination in this context were product-oriented. In music lessons, for example, taking into account students' imaginations and emphasizing different thinking can disclose new products that have never been developed before. Furthermore, if teachers incorporate some components that allow for the creative side of music in the classroom, they will be able to maximize the effectiveness of their instruction. Moreover, the teachers linked improvisation with imagination; musical activities were described as playing music spontaneously or making imaginary music related to narratives and fairy tales, and experimenting-exploring music with sounds of nature and their environment. These might be a part of the improvisatory pedagogy. This pedagogy should be considerably reconstructed and developed to place an explicit implementation in the school context for generating new ideas in terms of imagination. Therefore, musical thinking should be encouraged through the creative exploration of sounds and improvisational activities during the stage of children's imaginative play to control musical intentions and produce coherent and meaningful sounds (Kokotsaki, 2011). Teachers' perspectives in this study appear to support the importance of putting imagination into practice in primary music instruction. On the other hand, teachers associated creativity with thinking differently, developing critical thinking abilities, and allowing children to work independently, according to the findings. Craft (2002) emphasizes that creativity is not a skill that requires no prior knowledge. To shape their music teaching practices and meet the learning objectives for fundamental music pedagogy in primary education, teachers must be aware of this concept.

Another results showed that all of the teachers agreed that creativity is necessary for students to develop their learning skills as well as their imagination. This finding is consistent with Kampylis and Argyriou's (2008) research findings, which found that the majority of music teachers believe that creativity is an important aspect in personal and social development. In describing this phenomenon, teachers made links to product learning, which includes seeing students' products such as creating songs from stories or vice versa, making-playing their own instruments, creating 
rhythms with various objects, and writing poems-lyrics. These may be try-out activities to explore new ideas and may be a part of informal learning experiences for children. Teachers perceived creativity in primary music as students expressing their emotions through movements-dance, and improvising rhythmical patterns with percussion instruments. These statements mostly focused on the process rather than the product. Only a few music teachers' statements were about composing melodies and rhythms. There was no emphasis on structural and meaningful composing, as well as a lack of definitions about the products.

Mullet et al. (2016) pointed out that teachers need a clear understanding of the creative process, products, personality, and environmental factors to improve students' creative skills. In their study about examining teachers' perceptions of creativity, a systematic review of the literature was listed. The results indicated that teachers' conceptions of creativity were limited, vague, or confused. Teachers could not distinguish the concepts of creativity and creative product and lacked an explicit understanding of musical creativity and assessment.

Schools have a critical role in developing students' creative skills and attitudes to prepare them for the future, where innovative and creative experiences are appreciated. Virtually, it is teachers' responsibility to instil in students the need to learn and teach, enjoy themselves, see the world with eyes full of hope and to believe that everything can change (Bujez \& Mohedo, 2013); likewise, teachers need to show different ways and possibilities to their students to find their passion and their element (Robinson, 2009). Essentially, teachers have to acquire and develop an understanding of creativity to teach creatively in their music classes (Kokotsaki, 2012). The need for new conceptions of the 21st century for public school music teachers becomes distinctive in the contemporary context, as Campbell (2017) emphasises, the music teacher is an improviserperformer-composer, a musical thinker, humanist, social visionary, and sensitive world citizen (as cited in McPhail \& McNeil, 2019).

The results in this research showed that classroom and music teachers perceived creativity as developable for all students. One of the classroom teachers' illustrations was that students' creativity can be developed with good music education. Understanding of a 'good music education' is addressed to meeting the students' needs and considering their differences, characteristics, and experiences for developing creativity. Odena and Welsch (2009) reported in their research that most teachers believed all students have a capacity for creativity. This finding is consistent with the research findings in this study. In contrast to these results, Zbainos and Anastaspoulou's (2012) findings indicated that Greek teachers perceived creativity as a natural gift that could be developed in some students and partly taught in the music classroom.

From the perspective of creativity and considering students' imagination, all teachers seemed to have a positive attitude. Furthermore, classroom teachers believe that imagination and creativity can be developed in all lessons at the primary level, not only in music lessons. Some teachers connected musical creativity as product-based learning and made links with cross-curricular learning. Accordingly, if a new, quality product emerges at the end of the learning-teaching process by integrating music with other disciplines, the students' creativity can be strengthened somehow. This finding seems in one respect consistent with Barry and Durham's (2017) findings: pre-service teachers of early childhood education reported that music became a unifying theme for cross-curricular learning at the end of the practicum, which was based on a thematic approach integrating music with other content areas. The university students appreciated the crosscurricular connections that the children discovered through their experiences.

This research also intended to examine how teachers develop and implement good classroom practices to stimulate students' imagination and musical creativity. Music teaching methods and approaches (e.g. Orff-Schulwerk, Kodaly) were mentioned only by music teachers, since they were more familiar with the music teaching approaches during their education at university than the classroom teachers. According to the music teachers, these approaches allow students to express themselves freely through dance, movements, body percussions, and games, which have an impact on the development of creativity. Implementations and adaptations of practices to the 
culture and the national curriculum were emphasised, and the use of a variety of methods (drama and storytelling as teaching methods), which depends on the teacher's creativity, was stressed. From direct quotes in this research, we may understand that some teachers believe that supporting motivation and providing the necessary emotional environment can foster students' imagination and creativity in the music class.

The study results also showed that teachers prepare and apply student-centred activities by considering students' individual differences, and cooperative learning to foster imagination, which ends with products, as well as product-based projects. Some teachers considered planning and organising activities according to different grade levels. Performing was explained as rhythmical group exercises, body percussion activities, or conducting a group of instruments/orchestra. Lizacic and Susic (2020) carried out action research about the contribution of children's selforganised musical activities to preschool teachers' lifelong learning. The children's musical activities were encouraged, tracked, and documented. The self-organised musical activities were those in which the children created sounds with new instruments (noisemakers, drums, guitars, sound synthesisers etc.), independent playing on old and new musical instruments, and the Little Orchestra game, which seems to be the same activity as that used by one of the music teachers in this research. Other musical activities were creating stories from a piece of music (songs) with Orff instruments / solo instruments, creating their own rhythms-patterns, and instrumentmaking/playing. These activities were seen as improvisational music activities by the classroom and music teachers. The transferability of music to other subjects was the most mentioned aspect by the teachers.

In planning their music teaching for developing imagination and creativity, teachers indicated that they often use digital resources. Music teachers in private schools use a digital music education program/computer games to catch students' attention. Besides, classroom teachers benefit from music activities on YouTube or Instagram and adapting them to their classes. In this study, the classroom teachers emphasised the need for musical activities to support their music teaching and stated that they searched for seminars and workshops to learn how to implement musical classroom activities. Nevertheless, the easiest way to access such music activities is through the internet and social media materials. Music textbooks are used less often, as stated by all teachers; the reason was, for instance, that textbooks could include more colourful and remarkable pictures and should be designed professionally. In this way, many of the musical terms would be easier to understand.

Teachers were asked to give an example of a music lesson that stimulates students' imagination and creativity. Four teachers mentioned drama and dramatisation; stories and narratives were dramatised with songs and instruments. It can be said that teachers use such literary materials, role-play, and drama techniques to evoke students' imagination. Music was integrated with different subjects and disciplines (dance, drama, maths, social science, Turkish, values education) by most classroom teachers and some music teachers. Examples were activities such as speech singing (similar activity in Lizacic \& Susic, 2020) and playing or singing intrinsically and spontaneously while experimenting with sounds.

Listening activities were not mentioned in detail and were used mostly to invoke students' feelings, ideas and imaginations. Csikszentmihalyi (2017) argues that listening to music develops the ability to animate feelings and images based on human sound patterns and that what makes life better is not hearing but "listening". Therefore, intentionally, music teachers should improve students' listening skills with a well-structured teaching plan and practice. Decision making, working in groups, invoking the imagination for creativity, and creating a free classroom environment were used by most teachers to stimulate and develop students' imagination and creativity. Furthermore, rhythmic accompaniments were first interpreted with the body and other materials, and then transferred to instruments. These findings can be perceived as a kind of improvisation activities. The term 'improvisation' was not used much by the teachers during the interviews. However, improvisation in the music class may significantly impact students' musical 
skills and creative behaviour. Brophy (2005) examined the melodic improvisations of a group of children for three years (from 7 age to 9). Significant differences in melodic improvisations were found over the years. The results indicated that children's improvisations do change over time. Suggestions were that teachers should realistically accept these ideas/creations musically and encourage their students to improvise in many different contexts with many instruments. Following this, teachers' teaching experience has a crucial impact on children's musical development. For instance, Kokotsaki (2012) found that teaching experience is vital; all studentteachers in her study who held richer conceptions on describing creative music lessons were more articulate and comfortable in their responses. Koutsoupidou's (2005) research findings indicated that teachers with longer teaching experience included more improvisation activities in their music lessons; the reason for this was stressed as their increased self-confidence and teaching knowledge. These results show that the teacher's active engagement with improvisational music activities in the classroom and longer teaching experience can enable the development of imagination and creativity in primary music education. In this study, systematic observations are needed to reveal the effects of teachers' experiences and years of teaching on their creative engagement in their classes. For this reason, it does not seem possible to make determinations only through interviews because research findings show that there is a gap between teachers' valuation of creativity and their statements about the importance of creativity in students' learning and putting it into pedagogical classroom practices (Mullet et al., 2016). In the context of a 'life-wide learning' (Craft, 2002), building and implementing a curriculum for improvisatory music pedagogy and strengthening teachers' and pre-service teachers' teaching of music competencies with an imaginative and creative understanding seems essential.

Composing activities with musical intention were pointed out by a few music teachers. Some statements about the composition activities included combinations of musical ideas, motives, and phrases and creating meaningful sounds. However, the classroom teachers' illustrations were about unstructured and informal teaching of composing where mostly students explore and experiment with different sounds which end with a product according to their choices. Reimer (1997) emphasised the need for giving opportunities to compose to all children, and naturally, activities such as these are important since they offer a fertile field for developing musical creativity (as cited in $\mathrm{O}^{\prime}$ Callaghan, 2003). It is important to note that teachers need to prioritise time for reflection in the music curriculum because "once children and their teachers reflect on what improvising and composing mean to them, they will become better equipped and more likely to envisage what they could come to mean within and beyond the classroom" (Burnard, 2000 , p. 22). Herein, a spectacular music project with primary school students in Germany sets an extraordinary example of how creativity can be developed in schools. The project: "The HändelExperiment: Make your school famous" was for the first time integrated into the 2017/18 school year. The invitation to deal with composition in music lessons in an intense, exciting way is aimed at all classes and their teachers from the fifth grade onwards (students were inspired by the composer G.F.Händel's works). The music lessons became a creative composer's workshop for students. In a pilot project, interested participants were offered modern, intuitively usable software for music production. The "experiment" supports music teachers and their classes with free teaching materials and YouTube tutorials. The highlight was the final concert with the symphony orchestra and radio choir. Here, the students experienced what their musical ideas sound like when a symphony orchestra plays them. The concert was broadcast live across Germany on the radio and online as a video stream (Bundesverband Musikunterricht, [German Music Teacher Association], 2017, p. 29). It is inspiring to see how schools can go beyond their narrow boundaries and bring students' imagination and creativity to different dimensions. There is a bright and shining path that shows some promising developments regarding imagination and creativity in schools in the future.

Teachers' responses regarding the primary school music curriculum changes indicated that curriculum development is needed to focus on students' imaginative and creative potentials in the 
primary music class. Classroom teachers pointed out that more detailed musical curriculum activities and integration of music with other subjects and disciplines (drama, dance, science, maths etc.) are vital to obtain more instruction in conducting music teaching and music activities that stimulate students' music-making. They also noted the need for in-service teacher training and music courses to empower their music skills and competencies. Bainger's (2010) observations showed that with a collaborative and supportive environment, teachers' willingness to be active in their music classes with their students will increase and that this will also contribute significantly to an increase in the quantity and quality of children's learning and musical experiences (as cited in Barry \& Durham, 2017).

Many research studies have indicated that classroom teachers lack the confidence to teach music and conduct music activities and possess insufficient music competencies and teaching strategies (Barry \& Durham, 2017; Berke \& Colwell, 2004;; De Vries, 2011; Giles \& Frego, 2004; Hallam et al., 2009; Holden \& Button, 2006; Jeanneret, 1997; Russel-Bowie, 2013). At primary state schools in Turkey and some other countries, the classroom teacher is responsible for teaching music, and this creates a significant gap in music education since classroom teachers are mostly not specialised in music. In this study, the classroom teachers found it challenging to teach music and perceived themselves as not musically competent, which may block the development of children's musical creativity. The findings seem to be consistent with those of the other researchers, as mentioned previously. However, classroom teachers have positive beliefs in stimulating and developing students' imagination and creativity in music lessons and are aware of the importance of music activities in children's holistic development. Some music teachers suggested that changes should be made in music teacher training programmes that more courses should relate to dance and movement, and that didactic music courses should be included intensively in order to reach qualified music specialists. These illustrations are surprising; we understand that some music teachers are not satisfied with their university education. Lizacic and Susic (2020) noted that "the spontaneity and creativity of the child and the direct experience in musical and creative activities are forms of lifelong professional development and training of preschool teachers, who, because of the children, reinvent and excite their own, often repressed, creativity" (p. 83).

Moreover, music teachers emphasised the equality gap in primary music education and the music curriculum, in which they were concerned about its lack of developing students' imagination and creativity. They pointed out that each student has the right to receive an effective and meaningful music education and that talented children should be trained within a particular music curriculum. The updated Turkish primary music curriculum in 2006 emphasized studentcentered learning and included four learning areas based on constructivist learning, cooperative learning, and multiple intelligences theory. These are listening-singing-playing, musical perception and knowledge, musical creativity, and music culture. The current music curriculum came into force in 2018 and is based on the learning approaches mentioned above. It can be said that it is an updated version of the former music curriculum but with some changes. One of the changes is that the 'listening - singing - playing' learning area was modified to 'listening and singing', the instrument playing dimension was removed. However, music education without playing instruments will lead to some deficiencies in children's psychomotor skill acquisition and musical development (Albuz \& Demirci, 2018). Another curriculum gap is that the current curriculum consists of general explanations regarding assessment and evaluation, it lacks explanations and activities related to learning approaches, examples of music activities, and music teaching. Besides, some of the learning outcomes were partially changed, and some were removed such as "Playing sound-echo games, accompanying the music with the rhythm instruments that students have created, transforming simple rhythmic melodies into movements, forming movements appropriate to the lyrics of the songs they listen to and sings and then perform together, dramatising different events in stories by using different sound sources" (1st grade) and "Dramatising stories, they listen with different materials and voices. Students are encouraged to 
accompany their musical play with various improvised body movements" (2nd grade) (MoNE, 2018).

\section{Conclusion and Educational Implications}

The conclusions of this study may appear that teachers comprehend the necessity of instructions for music teaching and numerous instances of music activities in the music curriculum. A thorough understanding of developing a creative pedagogy in primary music education is required. Classroom instruction for younger grades should also include attention to composition, improvisation, and creative listening, besides singing and moving (Webster, 2018). Notably, the Creative Curriculum teaching guides used by pre-service teachers in Barry and Durham's (2017) study provided an essential source for planning and directing appropriate music experiences for children and student-teachers. Russel-Bowie (2013) conducted research that focused on the music module of the Primary Creative Arts unit, based on Kolb's Experiential Learning Model, to develop the confidence and attitudes of primary pre-service music education students. Students were asked to write an integrated arts program after several face-to-face and online courses and four to six weeks of music learning experiences. At the end of the study, the majority of $74 \%$ stated that writing an integrated arts program provided their sense of competence in teaching music and indicated that they would implement the creative arts program in the classroom. Another example of a Creative Curriculum embraced in a school in England gave teachers more freedom in planning and allowed teachers to focus more on what the children were interested in (Craft et al., 2014).

In this research, we may understand that teachers are aware of achieving the goals for students' musical creativity related to the learning outcomes of the primary music curriculum mentioned previously, but they (especially classroom teachers) need more supportive examples of various creative musical activities and an arts-integrated curriculum. As a researcher, at this point, I will go forward with an intuitive sense based on the emotional and intense atmosphere during the interviews; I can say that there are intentions and some efforts by teachers to develop imagination and musical creativity in their classrooms. However, consistently with this, there must be professional developments, improvements, and training to effectively achieve imaginative and creative potential in the music classroom. Hallam et al. (2009, p. 237) advocate that "governments, educational policymakers, and the teaching profession have a responsibility to ensure that every child has the opportunity to access a high-quality experience relating to the National Curriculum in music wherever they attend school."

One of the limitations of this study was that classroom observations were not included due to lack of time. The interviews with each teacher and their analysis took a long time. Another reason was that this research intended to examine teachers' perceptions in developing imagination and creativity in primary music education through a phenomenological approach and determined the status of the two phenomena in Turkey's primary music education. Follow-up qualitative studies are recommended with observation methodology to examine the development of imagination and creativity in the music classroom with a more extensive study group of teachers and students in Turkey's different regions. Additionally, a cross-country comparison of developments related to imagination and creativity in primary music education can be conducted. Besides, models for an Imaginative and Creative Curriculum can be designed, and the basis for implementations can be carried out after several pilot studies. Educational policies and curriculum development should frame the encouragement of cross-curriculum creativity and creative teaching strategies. Furthermore, recognising a creativity spectrum from 'little $c^{\prime}$ (everyday creativity) to 'big C' (higher creativity, paradigm-shifting creativity) (Craft et al., 2014; Craft, 2002) may be critical concepts for the growth of creativity in education. However, to nurture and foster imagination and creativity in primary music education, we need to consider and value the 'little c'. As Craft (2003) describes, "little c creativity is not necessarily tied to a product-outcome, for it involves exercising imaginativeness. Nevertheless, it involves having some grasp of the domain of application and 
thus of the appropriateness of the ideas. It involves the use of imagination, intelligence and selfexpression" (p. 148).

It is possible to see extraordinary examples in different countries as to what kind of goals can be achieved in education when programmes, curricula and lessons are created according to students' identities, special interests, and capacities. In his book, Professor Sir Ken Robinson (2015) shares challenging and exciting examples of schools and teachers who are very enthusiastic about developing students' creativity. He refers to teachers who initiated various creative projects and programmes to provide time and space for students to find their own creative processes. We need to consider these examples and efforts; more importantly, we may learn from these inspiring events, which will let us take the encouraging steps further.

\section{"...music should allow you to imagine" (I. Maalouf, performer-composer)}

\section{References}

Albuz, A., \& Demirci, B. (2018). A comparative theoretical framework analysis on the music course 2006 teaching program in primary education and 2018 teaching program in primary and secondary education. Journal of the Fine Arts Institute, 41, 86-95. https:/ / doi.org/10.32547/ataunigsed.463634

Amankwaa, L. (2016). Creating protocols for trustworthiness in qualitative research. Journal of Cultural Diversity, 23(3), 121-127.

Barry, N. H., \& Durham, S. (2017). Music in the early childhood curriculum: Qualitative analysis of preservice teacher's reflective writing. International Journal of Education $\&$ the Arts, 18(16), 1-18.

Baskale, H. (2016). Determination of validity, reliability and sample size in qualitative studies, Dokuz Eylul University E-Journal of Nursing Faculty, 9(1), 23-28.

Berke, M., \& Colwell, C. M. (2004). Integration of music in the elementary curriculum: Perceptions of preservice elementary education majors. Applications of Research in Music Education,23(1), 22-33. https://doi.org/10.1177/87551233040230010104

Boyatzis, R. E. (1998). Transforming qualitative information: Thematic analysis and code development. Sage Publications.

Brophy, T. S. (2005). A longitudinal study of selected characteristics of children's melodic Improvisations, Journal of Research in Music Education, 53(2), 120-133. https:/ / doi.org/10.1177/002242940505300203

Bujez, A. V., \& Mohedo, M. T. D. (2014). Creativity in the music classroom. Procedia - Social and Behavioural Sciences, 141, 237-241. https://doi.org/10.1016/j.sbspro.2014.05.041

Bundesverband Musikunterricht aktuell (2017). Das Händel-experiment macht schüler zu komponisten. [The Handel experiment turns students into composers]. Journal of the German Music Teacher Association (BMU), 5, 1-48.

Burnard, P. (2000). How children ascribe meaning to improvisation and composition: re-thinking pedagogy in music education. Music Education Research, 2(1), 7-23. https:// doi.org/10.1080/14613800050004404

Chambliss, J. J. (1991). John Dewey's idea of imagination in philosophy and education. The Journal of Aesthetic Education, 25(4), 43-49. https://doi.org/10.2307/3332902

Connelly, L. M. (2010). What is phenomenology? MedSurg Nursing, 19(2), 127-128.

Craft, A. (2002): Creativity and early years education: A life-wide foundation. Continuum.

Craft, A. (2003). Creative thinking in the early years of education. Early Years: An International Journal of Research and Development, 23(2), 143-154. https:// doi.org/10.1080/09575140303105

Craft, A., Cremin, T., Hay, P., \& Clack, J. (2014). Creative primary schools: developing and maintaining pedagogy for creativity. Ethnography and Education, 9(1), 16-34. https://doi.org/10.1080/17457823.2013.828474

Csikszentmihalyi, M. (2017). Flow: The psychology of optimal experience. Harper Perennial.

Dall'Alba, G. (2009). Phenomenology and education: An introduction. Educational Philosophy and Theory, 41(1), 7-9. https:// doi.org/10.1111/j.1469-5812.2008.00479.x

De Vries, P. (2011). The first year of teaching in primary school: Where is the place of music?. International Journal of Education \& the Arts, 12(2), 1-25.

Dogani, K. (2004). Teachers' understanding of composing in the primary classroom. Music Education Research, 6(3), 263-279. https://doi.org/10.1080/1461380042000281721

Eagleman, D., \& Brandt, A. (2017). The runaway species: How human creativity remakes the world. Cannongate Books. 
Elo, S., Kääriäinen, M., Kanste, O., Pölkki, T., Utriainen, K., \& Kyngäs, H. (2014). Qualitative content analysis: A focus on trustworthiness. SAGE Open, 4(1), 1-10. https://doi.org/10.1177/2158244014522633

Fereday, J., \& Muir-Cochrane, E. (2006). Demonstrating rigour using thematic analysis: A hybrid approach of inductive and deductive coding and theme development, International Journal of Qualitative Methods, 5(1), 80-92. https:// doi.org/10.1177/160940690600500107

Giles, A. M., \& Frego, R. D. (2004). An inventory of music activities used by elementary classroom teachers: An exploratory study. Applications of Research in Music Education, 22(2), 13-22. https://doi.org/10.1177/87551233040220020103

Guest, G., MacQueen, K. M., \& Namey, E. E. (2012). Applied thematic analysis. Sage Publications.

Hallam, S. (2010). The power of music: Its impact on the intellectual, social and personal development of children and young people. International Journal of Music Education,28(3), 269-289. https:// doi.org/10.1177/0255761410370658

Hallam, S., Burnard, P., Robertson, A., Saleh, C., Davies, V., Rogers, L., \& Kokatsaki, D. (2009). Trainee primary-school teachers' perceptions of their effectiveness in teaching music. Music Education Research, 11(2), 221-240. https:/ / doi.org/10.1080/14613800902924508

Harris, P. L. (2000). The work of the imagination. Blackwell Publishing.

Hickey, M., \& Webster, P. (2001). Creative thinking in music. Music Educators Journal, 88(1), 19-23.

Higgins, C. (2008). Modest beginnings of a radical revision of the concept of imagination. In R. Fitzgerald, \& T. W. Nielsen (Eds.), Imaginative practice, imaginastive inquiry, proceedings of the sixth international conference on rmagination and education (pp. 36-47). University of Canberra Press.

Holden, H., \& Button, S. W. (2006). The teaching of music in the primary school by the non-music specialist, The British Journal of Music Education, 23(1), 23-38. https://doi.org/10.1017/S0265051705006728

Hycner, R.H. (1985). Some guidelines for the phenomenological analysis of interview data. Human Studies, 8, 279-303. https://doi.org/10.1007/BF00142995

Jeanneret, N. (1997). Model for developing pre-service primary teachers' confidence to teach music. Bulletin of the Council for Research in Music Education, 133, 37-44. https:/ / doi.org/10.2307/3399772

Joubert, M. M. (2001). The art of creative teaching: NACCCE and beyond. In A. Craft, B. Jeffrey, \& M. Leibling (Eds), Creativity in education (pp. 17-34). Continuum.

Kampylis, P. G., \& Argyriou, M. (2008). Music teachers' perceptions of creativity and their role in students' creative thinking development. In A. Daubney, E. Longhi, A. Lamont \& D. Hargreaves (Eds.), Musical development and learning, proceedings of the second european conference on developmental psychology of music (pp. 149-154). GK Publishing.

Kettler, T., Lamb, K. N., Willerson, A., \& Mullet, D. R. (2018). Teachers' perceptions of creativity in the classroom. Creativity Research Journal, 30(2), 164-171. https:/ / doi.org/10.1080/10400419.2018.1446503

Kokotsaki, D. (2012). Pre-service student-teachers conceptions of creativity in the primary music classroom. Research Studies in Music Education, 34(2), 129-156. https:// doi.org/10.1177/1321103X12466770

Kokotsaki, D. (2011). Student teachers' conceptions of creativity in the secondary music classroom. Thinking Skills and Creativity, 6, 100-113. https://doi.org/10.1016/j.tsc.2011.04.001

Koutsoupidou, T. (2005). Improvisation in the English primary music classroom: Teachers' perceptions and practices. Music Education Research, 7(3), 363-381. https://doi.org/10.1080/14613800500324432

Koutsoupidou, T. (2008). Effects of different teaching styles on the development of musical creativity: Insights from interviews with music specialists. Musicae Scientiae, 12(2), 311-335. https://doi.org/10.1177/102986490801200207

Langley, D. W. (2018). Students' and teachers' perceptions of creativity in middle and high school choral ensembles. Music Education Research, 20(4), 446-462. https:/ / doi.org/10.1080/14613808.2018.1433150

Lizačić, V., \& Sušić, B. B. (2020). Contribution of children's self-organised musical activities to the lifelong learning of preschool teachers. Croatian Journal of Education, 22(3), 83-100. https://doi.org/10.15516/cje.v22i0.3911

McPhail, G., \& McNeill, J. (2019). One direction: A future for secondary school music education?. Music Education Research, 21(4), 359-370. https://doi.org/10.1080/14613808.2019.1605345

Ministry of National Education. (2018). Primary and secondary school music lesson teaching. http://mufredat.meb.gov.tr/ProgramDetay.aspx?PID=357

Mullet, D. R., Willerson, A., Lamb, K. N., \& Kettler, T. (2016). Examining teacher perceptions of creativity: A systematic review of the literature. Thinking Skills and Creativity, 21, 9-30.

O'Callaghan, E. (2003). On implementing the new music curriculum in primary schools. Irish Educational Studies, 22(3), 45-56. https:/ / doi.org/10.1080/0332331030220307 
Odena, O., \& Welch, G. (2009). A generative model of teachers' thinking on musical creativity. Psychology of Music, 37(4), 416-442. https:/ / doi.org/10.1177/0305735608100374

Reesman, J. (2015). Creative Thinking in the Elementary Music Classroom: A Review of Literature (Unpublished Doctoral dissertation). University of Florida, USA.

Reichling, M. J. (1997). Music, imagination, and play. The Journal of Aesthetic Education, 31(1), 41-55. https:// doi.org/10.2307/3333470

Robinson, K., \& Aronica, L. (2009). The element: How finding your passion changes everything. Penguin Books.

Robinson, K., \& Aronica, L. (2015). Creative schools: The grassroots revolution that's transforming education (6th ed.). Penguin Books.

Russell, D. (1998). Cultivating the imagination in music education: John Dewey's theory of imagination and its relation to the Chicago Laboratory school. Educational Theory, 48(2), 193-210.

Russell-Bowie, D. (2013). Mission impossible or possible mission? Changing confidence and attitudes of primary pre-service music education students using Kolb's experiential learning theory. Australian Journal of Music Education, 2, 46-63.

Ryan, T. G., \& Brown, K. (2012). Musical creativity: Measures and learning. Journal of Elementary Education, 22(2), 105-120.

Selvi, K. (2014). PhenoMethod-a new teaching and learning method design. International Journal of Curriculum and Instructional Studies, 4(8), 43-53.

Skiba, T., Tan, M., Sternberg, R. J., \& Grigorenko, E. L. (2010). Roads not taken, new roads to take: Looking for creativity in the classroom. In R. A. Beghetto \& J. C. Kaufman (Eds.), Nurturing creativity in the classroom (pp. 252-269). Cambridge University Press. https:// doi.org/10.1017/CBO9780511781629.013

Sungurtekin, S., \& Kartal, H. (2020). Listening to colourful voices: how do children imagine their music lessons in school? International Online Journal of Primary Education, 9(1), 73-84.

Trivedi, S. (2017). Imagination, music, and the emotions: A philosophical study. Suny Press.

Webster, P. R. (1990). Creativity as creative thinking. Music Educators Journal, 76(9), 22-28. https:// doi.org/10.2307/3401073

Webster, P. R. (2002). Creative thinking and music education: Encouraging students to make aesthetic decisions. In Proceedings of the 10th Anniversary European Society for the Cognitive Sciences of Music, Musical Creativity Conference. University of Liege.

Webster, P. (2018). Re-thinking music education: Encouraging creative thinking in sound across all musical experiences. ISME-International Society for Music Education.

Zbainos, D., \& Anastasopoulou, A. (2012). Creativity in Greek music curricula and pedagogy: An investigation of Greek music teachers' perceptions. Creative Education, 3(1), 55-60. https://doi.org/10.4236/ce.2012.31009 